\title{
Pengaruh Variabel Harga dan Citra Perusahaan terhadap Keputusan Pembelian Produk Wingsfood
}

\author{
Ella Anastasya Sinambela1 ${ }^{1}$, Putri Purnama Sari², Samsul Arifin ${ }^{3}$ \\ 1,2,3Fakultas Ekonomi Universitas Mayjen Sungkono Mojokerto \\ email:1easinambela@gmail.com, 2purnama9998@gmail.com, ${ }^{3}$ arifin.unimas@gmail.com
}

\section{Kata kunci:}

Harga

Citra Perusahaan

Keputusan Pembelian

\section{Keywords: \\ Price \\ Corporate Image \\ Purchase Decision}

Ella Anastasya Sinambela ${ }^{1}$, Putri Purnama Sari², Mila Hariani ${ }^{3}$. (2020). Pengaruh Harga dan Citra Perusahaan terhadap Keputusan Pembelian Produk Wingsfood. Akuntabilitas: Jurnal Ilmiah Ilmu-Ilmu Ekonomi, 13(1) 2020, 55-70

\begin{abstract}
ABSTRAK
Dunia bisnis yang melibatkan perusahaan-perusahaan ternama semakin menunjukkan persaingan melalui penjualan produk-produknya dan upaya untuk menguasai pasar. Salah satu korporasi ternama di Indonesia adalah Wingsfood yang telah memiliki pelanggan-pelanggan loyal karena mempercayai produk-produk yang dihasilkannya sejak memasuki pasarnya. Penelitian ini bertujuan untuk mengetahui pengaruh harga dan citra perusahaan terhadap keputusan pembelian produk Wingsfood dikota Mojokerto. Sampel diambil sebanyak 143 responden. Alat analisis yang digunakan adalah SPSS 25. Teknik pengambilan sampel penelitian ini menggunakan pengambilan secara acak. Skala kuesioner menggunakan skala likert. Data terdiri dari data primer yang diambil dari kuesioner yang disebarkan secara langsung kepada responden. Analisis yang digunakan untuk mengkaji pengaruh harga dan citra perusahaan adalah analisis linier berganda. Dari hasil pengolahan data diperoleh persamaan regresi $\mathrm{Y}=$ $2,211+0,387+0,869 X 2$. Penelitian menunjukkan beberapa temuan, yaitu (1) harga berpengaruh signifikan terhadap keputusan pembelian produk Wingsfood dikota Mojokerto, (2) citra perusahaan berpengaruh signifikan terhadap keputusan pembelian produk Wingsfood di kota Mojokerto, (3) harga dan citra perusahan berpengaruh secara simultan terhadap keputusan pembelian produk Wingsfood di koto Mojokerto.
\end{abstract}

\section{ABSTRACT}

The business world involving well-known corporations is increasingly showing competition through the sale of its products and efforts to dominate the market. One of the well-known corporations in Indonesia is Wingsfood which already has loyal customers because it trusts the products it produces since entering its market. This study aims to determine the effect of price and company image on purchasing decisions of Wingsfood products in the city of Mojokerto. Samples were taken as many as 143 respondents. The analytical tool used is SPSS 25. The research sampling technique uses random sampling. The questionnaire scale uses a Likert scale. Data consists of primary data taken from questionnaires distributed directly to respondents. The analysis used to examine the effect of price and company image is multiple linear analysis. From the results of data processing the regression equation $Y=-2.211+0.387+0.869 X 2$ is obtained. Research shows several findings, namely (1) price significantly influences the purchasing decisions of Wingsfood products in the city of Mojokerto, (2) company image has a significant effect on purchasing decisions of Wingsfood products in Mojokerto, (3) price and image of the company have a simultaneous effect on product purchasing decisions Wingsfood in koto Mojokerto.

Pengaruh Harga dan Citra Perusahaan terhadap Keputusan Pembelian Produk Wingsfood 


\section{PENDAHULUAN}

Dunia bisnis mengalami era globalisasi yang disertai dengan persaingan yang sangat ketat. Perusahaan harus beradaptasi terhadap perkembangan yang sedang terjadi saat ini. Untuk dapat bertahan, para pelaku bisnis harus memahami kebutuhan dan keinginan pasar. Produk yang dihasilkan mereka menjadi komoditas yang menunjukkan keberhasilan memasuki pasar.

Kehidupan sehari-hari manusia mempunyai kebutuhan yang bermacammacam. Salah satu kebutuhan manusia yang paling penting adalah kebutuhan untuk makan. Seiring berkembangnya zaman manusia membutuhkan sesuatu yang serba cepat dan praktis. Di industri makanan kemasan semakin banyak produsen yang memperebutkan bagian pasar yang lebih luas. Mereka yang mendatangkan beragam produk unggulan untuk memasuki pasar dengan merek-merek baru. Beragama cara pun melalui kegiatan pemasaran, para produsen berusaha mengenalkan merek-merek mereka agar produk yang dihasilkan dapat diterima di pasar.

Wingsfood adalah salah satu korporasi terkemuka di Indonesia berada di bawah naungan Wings Group. Inovasi yang dilakukan Wings Group memunculkan Wingsfood yang berfokus pada produk makanan. Wings mengadakan inovasi dengan mengeluarkan wingsfood. Merek induk yang melakukan perluasan dan pengembangan merek dengan sub merek memudahkan untuk lebih cepat dikenal oleh pasar dan nilai merek akan melekat dibantu dengan reputasi merek yang lebih dulu tertanam kuat di benak para pengguna merek (Darmawan, 2011). Wings yang telah memiliki pelangganpelanggan loyal telah memiliki pangsa pasar yang masih dapat dikembangkan lebih luas dibandingkan sekarang. Reputasi merek dari merek induk telah menyebabkan inovasi produk menjadi lebih mudah diterapkan pada produk baru dan ditawarkan kepada pasar. Produk wingsfood yang telah memiliki ekuitas merek yang kuat diantaranya : Jasjus, Segar Dingin, Mie Sedaap, Kecap Sedap, Ale-ale dan sebagainya.

Indofood bersama produsen lainnya merupakan pesaing bagi Wingsfood di bidang makanan. Mereka memahami kebutuhan dasar manusia terhadap kebutuhan fisik berupa makanan. Saat ini tren masyarakat yang lebih memilih untuk mengkonsumsi makanan instan atau cepat saji telah menjadi dasar kemunculan produk-produk mereka. Salah satu strategi yang sering digunakan oleh para produsen 
adalah strategi komunikasi pemasaran dengan memanfaatkan reputasi korporasi serta menawarkan harga menarik dan berusaha meningkatkan popularitas merek. Dodds (1991) mengatakan harga memiliki pengaruh positif untuk keinginan membeli. Selain itu juga memunculkan merek tandingan produk makanan berbagai varian rasa. Dodds (1991) menyatakan merek tandingan pada harga memiliki pengaruh negatif terhadap keinginan untuk membeli. Efektivitas penerapan straegi pemasaran menyebabkan keberhasilan atau kegagalan memasuki pasar produk makanan. Meski demikian, komponen harga merupakan faktor yang dapat menjadi penentu hal tersebut selama para produsen dapat menyeimbangkan total biaya produksi dan hasil penjualan untuk memperoleh marjin keuntungan yang optimal bagi mereka.

Harga dalam bauran pemasaran yang menghasilkan pendapatan, unsur-unsur lainnya yang menghasilkan biaya (Darmawan, 2014). Menurut Satit et al. (2012) harga adalah salah satu elemen bauran pemasaran yang paling mempengaruhi keputusan pembelian pelanggan. Kegiatan penentuan harga memainkan peranan penting yaitu menentukan harga yang terkait langsung dengan pendapatan yang diterima perusahaan. Kotler dan Keller (2012) menyatakan penetapan harga menjadi hal yang paling penting untuk diperhatikan oleh perusahaan. Keputusan bauran harga berkenan dengan kebijakan strategi dan taktikal, seperti tingkat harga, struktur diskon, syarat pembayaran, dan tingkat diskriminasi harga di antara berbagai kelompok pelanggan.

Harga telah dijadikan sebagian besar konsumen sebagai pedoman menentukan keputusan pembelian. Harga memunculkan kesan kualitas produk. Konsumen akan lebih tertarik untuk melakukan pembelian ulang terhadap suatu produk jika harga yang ditetapkan oleh perusahaan tersebut sesuai dengan kualitas dari perusahaan tersebut. Harga juga memainkan peranan yang penting dalam kualitas dari produk. Darmawan (2019) menyatakan ketepatan menyesuaikan harapan pengguna dengan kualitas yang melekat di produk yang didukung dengan penetapan harga yang sesuai dengan kemampuan target pasar akan memunculkan kepuasan bagi penggunanya. Asosiasi merek dari produk berperan juga terhadap hal tersebut. Tanpa adanya informasi dan petunjuk yang nyata, target pasar mengasosiasikan harga yang tinggi dengan tingkat kinerja suatu produk yang tinggi pula. Zeithaml (1998) maupun Naehyun et al. (2016) menyatakan bahwa ada 
hubungan antara persepsi tentang kualitas dan harga. Kualitas yang baik diikuti dengan harga yang tinggi. Naehyun et al. (2016) menunjukkan bahwa persepsi konsumen terhadap kewajaran harga akan dibandingkan dengan harga dari produk yang sama.

Selain faktor harga, citra perusahaan juga memegang peranan sangat penting dalam lingkungan pasar yang sangat kompetitif saat ini. Citra perusahaan diartikan sebagai tanggapan yang ditunjukkan konsumen terhadap perusahaan mengenai segala penawaran termasuk gagasan tentang produk. Gagasan tersebut berwujud produk yang dikomunikasikan kepada pasar sasaran (Weiwei, 2007). Citra perusahaan sebagai aset strategis perusahaan yang unik dan tidak dapat ditiru, reputasi perusahaan memainkan peran sentral dalam mendapatkan keunggulan kompetitif dan meningkatkan kinerja bisnis (Hall, 1993 dan Barney, 1991). Sesuai dengan pendekatan pendekatan identitas sosial, Fombrun dan Shanley (1990) mengemukakan reputasi perusahaan sebagai penilaian kumulatif publik perusahaan dari waktu ke waktu; dan Weigelt dan Camerer (1988) mendefinisikannya sebagai seperangkat atribut yang dianggap berasal dari perusahaan, tidak terkait dengan tindakan masa lalu perusahaan. Demikian pula, Herbig et al. (1994) mendefinisikan reputasi perusahaan sebagai gabungan agregat dari semua transaksi sebelumnya selama masa entitas - yaitu, sebagai gagasan historis yang dibentuk melalui konsistensi tindakan selama periode waktu yang lama.

Citra perusahan dapat memperkuat citra merek produk-produk yang dihasilkannya (Darmawan, 2011). Meskipun perusahaan secara tradisional dapat mempertahankan keuntungan melalui batasan tinggi yang difasilitasi oleh strategi diferensiasi produk dan segmentasi pasar, saat ini perusahaan mengalami kesulitan untuk membedakan produk mereka, bahkan dengan anggaran penelitian dan pengembangan yang besar. Setiap inovasi cepat ditiru oleh pesaing. Berbagai jenis reputasi juga telah disarankan, termasuk menjadi pesaing yang tangguh menyediakan tempat yang baik untuk bekerja dan memiliki produk berkualitas (Gatewood et al., 1993; Shapiro, 1983). Demikian pula setiap perusahaan yang berhasil mengidentifikasi dan mengeksploitasi segmen yang kurang terlayani juga disalin. Untuk mengatasi situasi ini, pemasaran beralih ke strategi pemasaran hubungan, di mana mereka 
bergantung pada biaya transaksi yang lebih rendah dari pada keunggulan produk yang dirasakan untuk memenangkan dukungan pelanggan. Memperluas konsep ini menjadi transaksi dengan berbagai pemangku kepentingan dari pelanggan hingga karyawan serta regulator pemerintah (Cannon dan Schwaiger, 2005).

Citra perusahaan melekat pada kinerja produk dan hal tersebut ditunjukkan melalui kualitas. Selanjutnya dihubungkan dengan citra yang diasosiasikan dengan nama merek. Selain itu kegiatan bauran promosi seperti periklanan dan promosi penjualan dapat memperkuat citra perusahaan (Darmawan et al., 2019). Berman dan Evans (1995) menyatakan citra perusahaan dapat berperan sebagai kombinasi fungsional dan secara emosional. Hal ini berarti pengalaman sebelumnya berhubungan dengan perusahaan termasuk informasi yang tidak berpengalaman seperti iklan, efek dari mulut ke mulut dan prediksi memenuhi harapan di masa depan yang memiliki pengaruh positif ke arah pada kepuasan. Citra perusahaan ditinjau berdasarkan beberapa hal. Kompetensi dan keunggulan bersaing adalah diantaranya. Selain itu, pengalaman perusahaan untuk memasuki pasar sehingga dengan dasar pengetahuan dan pengalaman, mereka dapat beradaptasi dan peka terhadap kebutuhan pasar (Brown dan Dacin, 1997).

Menurut Darmawan (2011), citra perusahaan dan reputasi perusahaan merupakan hal yang menjadi satu kesatuan persepsi bagi penggunanya. Mereka akan terbantukan melibatkannya dalam prosese pengambilan keputusan dan dihubungkan dengan kualitas. Citra perusahaan maupun reputasi perusahaan terbentuk berdasarkan persepsi penggunanya dan berdasarkan pengalamannya, hal tersebut memperkuat persepsi mereka terhadap kualitas produk yang dihasilkan produsen. Citra perusahaan kompetensi perusahaan dalam sudut pandang pelanggan dapat dijadikan jaminan bagi pelanggan untuk menilai kualitas produk. Citra perusahaan yang baik menurut penggunanya dapat menyebabkan mereka bertahan sebagai pengguna atau mereka menjadi loyal (Ishaq, 2012). Bagi mereka yang belum menjadi pengguna suatu produk bermerek tertentu, citra perusahan mampu menjadi elemen yang dipertimbangkan sebelum mengambil keputusan pembelian (Brown dan Dacin, 1997). Selain itu keputusan pembelian juga mempertimbangkan kualitas, harga dan produk yang sudah dikenal. 
Keputusan pembelian termasuk tindakan seorang calon konsumen untuk memilih suatu produk dengan segala pertimbangan yang ada. Sikap konsumen memutuskan pembelian dapat berubah-ubah dengan cepat sesuai dengan banyaknya informasi yang muncul atau faktor yang mempengaruhi dari dalam maupun dari luar dirinya. Sinclair (2007) mengatakan proses pengambilan keputusan konsumen tidak rasional dalam arti bahwa itu objektif dan konsisten juga tidak mengikuti pola ekonomi statistik yang rasional dan ditentukan sebelumnya. Keputusan pembelian merupakan beragam pilihan merek produk terkait keputusan pembelian yang harus ditentukan oleh calon pembeli (Schiffman dan Kanuk, 2008). Adanya pilihan menyebabkan konsumen mempertimbangkan sebagai upaya meraih tingkat pemenuhan kebutuhan yang maksimal. Blackwell et al. (2006) menyatakan selama keputusan konsumen proses pembelian, mereka didorong oleh lingkungan mereka atau konteks di sekitar mereka yang memainkan peran penting untuk memengaruhi atau mengarahkan keputusan mereka. Lingkungan ini termasuk status sosial, budaya, motif pribadi, keluarga, dan faktor lainnya. Senecal dan Nantel (2004) juga menemukan itu sebelum membeli jenis produk atau layanan tertentu, banyak pelanggan menyukai saran membaca yang diberikan oleh yang berpengalaman pelanggan untuk membaca informasi produk secara khusus diumum. Pendapat yang diberikan oleh pelanggan berpengalaman adalah ditemukan secara signifikan memengaruhi pembelian pelanggan baru pengambilan keputusan.

Uraian tersebut dapat menjadi dasar untuk mengamati variabel harga dan citra perusahaan mempengaruhi keputusan pembelian. Para peneliti akan melakukan penelitian dengan judul Pengaruh Variabel Harga dan Citra Perusahaan terhadap Keputusan Pembelian Produk Wingsfood di Kota Mojokerto. Berdasarkan judul yang telah dinyatakan maka rumusan masalah dinyatakan sebagai berikut: (1) apakah harga berpengaruh signifikan terhadap keputusan pembelian produk Wingsfood di kota Mojokerto? (2) apakah citra perusahaan berpengaruh signifikan terhadap keputusan pembelian produk Wingsfood di kota Mojokerto? (3) apakah harga dan citra perusahaan berpengaruh signifikan secara simultan terhadap keputusan pembelian produk Wingsfood di kota Mojokerto ? 


\section{METODE PENELITIAN}

Metode penelitian yang digunakan di penelitian ini adalah kualitatif dengan metode survei, yaitu penelitian yang mengambil sampel dari suatu populasi dengan menggunakan kuesioner sebagai alat pengumpulan data utama. Subjek penelitian ini adalah 143 konsumen pembelian produk Wingsfood. Teknik pengambilan sampel menggunakan teknik pengambilan sampel secara acak. Darmawan (2015) mengatakan penetapan jumlah sampel di bidang pemasaran dengan ruang lingkup yang tidak luas dapat menggunakan 100 responden sebagai batasan minimal tetapi sifat populasi harus terwakili dan hal tersebut juga dapat disesuaikan dengan topik penelitian. Hair et al. (2010) mengatakan bahwa ukuran sampel yang representatif adalah antara 100-200 sampel. Jumlah yang sampel yang digunakan dalam penelitian ini sebanyak 143 responden. Penelitian ini terdiri dari variabel bebas adalah harga (XI), dan citra perusahaan (X2). Variabel terikat pada penelitian ini adalah keputusan pembelian $(\mathrm{Y})$. Penelitian ini menitikberatkan pada pengaruh harga dan citra perusahaan terhadap keputusan pembelian produk Wingfood. Penulis memilih produk Wingfood di kota Mojokerto, Jawa Timur.

Ada tiga variabel yang dilibatkan yaitu harga, citra perusahaan dan keputusan pembelian. Variabel bebas pertama (X1) adalah harga ialah kegiatan penentuan harga memainkan peranan penting dalam proses bauran pemasaran karena penentuan harga terkait langsung nantinya dengan pendapatan yang diterima oleh perusahaan. Menurut Kotler dan Armstrong (2006) yang mencirikan harga yang digunakan di penelitian ini sebagai dimensi, yaitu: (1) keterjangkauan harga ;(2) kesesuaian harga dengan kualitas produk; (3) daya saing harga. Variabel bebas kedua (X2) adalah citra perusahaan. Menurut Brown dan Dacin (1997) ada tiga dimensinya, yaitu (1) pengalaman untuk memasuki pasar; (2) kompetensi perusahaan; (3) keunggulan bersaing. Variabel terikat (Y) adalah keputusan pembelian sebagai keputusan konsumen yang mengenai preferensi atas setiap merek yang ada dalam kumpulan pilihan. Menurut Thomson (2013) ada empat dimensi dalam keputusan pembelian yaitu : (1) sesuai kebutuhan; (2) mempunyai manfaat; (3) ketepatan dalam membeli produk; (4) pembelian berulang. 
Skala penilaian yang digunakan adalah skala likert dengan rentang nilai 1-8 (Sangat Setuju Sekali=8, Sangat Setuju=7, Setuju=6, Cukup Setuju=5, Kurang Setuju=4, Tidak Setuju=3, Sangat Tidak Setuju=2, Sangat Tidak Setuju Sekali=1) . Software yang digunakan adalah SPSS 25 sebagai keperluan pengolahan data. Setelah pengumpulan data maka dilakukan uji reliabilitas dan validitas data. Selanjutnya dilakukan uji asumsi klasik yang terdiri dari uji normalitas, uji autokorelasi, uji heterokedastisitas, dan uji multikolonieritas. Uji kelayakan data dilanjutkan dengan uji hipotesis yang terdiri dari uji t dan uji $F$.

\section{PEMBAHASAN}

Penelitian ini dilakukan dengan cara menyebarkan kuesioner kepada responden berjumlah 143 responden. Pengumpulan data yang diperoleh menunjukkan adanya karakteristik responden seperti ditunjukkan pada tabel 1 .

Tabel 1

Profil Responden

\begin{tabular}{clcc}
\hline \multirow{3}{*}{ Gender } & & Frekuensi & Persentase \\
\cline { 2 - 4 } & Laki-laki & 62 & 43,4 \\
\cline { 2 - 4 } & Perempuan & 81 & 56,6 \\
\cline { 2 - 4 } Usia & Total & 143 & 100,0 \\
\cline { 2 - 4 } & $18-22$ & 69 & 45,5 \\
& $23-27$ & 58 & 39,3 \\
& $28-32$ & 13 & 10,7 \\
& $33-37$ & 2 & 4,5 \\
\cline { 2 - 4 } & Total & 142 & 100,0 \\
\hline
\end{tabular}

Sumber: data diolah oleh peneliti, 2020

Pada hasil penelitian ini diketahui dari jumlah penyebaran kuesioner. Berdasarkan jenis kelamin, jumlah responden dalam penelitian ini tidak jauh berbeda selisih antara laki-laki dan perempuan. Ada 62 responden laki-laki dan 81 responden wanita. Hal ini penelitian menentukan bahwa responden wanita di keputusan pembelian produk Wingsfood mempunyai daya pembelian yang konsumtif. Hasil penelitian ini diketahui bahwa usia responden dikelompokkan menjadi empat bagian. Berdasarkan pengelompokan tersebut usia 18-22 tahun ada 69 responden, hal ini penelitian menentukan bahwa responden dalam usia tersebut menyukai makanan cepat saji serta gaya hidup. Pada rentang usia 23-27 ada 58 responden. Hal ini menunjukkan bahwa responden dalam usia tersebut kebanyakan para pekerja lebih 
mudah untuk memenuhi kebutuhan dan membeli makanan cepat saji yaitu produk wingsfood. Pada rentang usia 28-32 tahun ada 13 responden yang berarti responden dalam usia tersebut memiliki daya konsumtif tinggi atau mencoba-coba dalam produk Wingsfood. Pada rentang usia 33-37 sejumlah dua responden, usia tersebut rentan untuk memakan makanan cepat saji karena faktor usia. Dengan demikian, mencerminkan empat bagian tersebut yang memiliki daya keputusan pembelian produk Wingsfood di kota Mojokerto yang tinggi adalah usia 18-22 tahun.

Tabel 2

Uji Validitas

\begin{tabular}{|c|c|c|c|c|}
\hline No & Variabel & Topik Pertanyaan & $\begin{array}{l}\text { Corrected } \\
\text { item- total } \\
\text { Correlation }\end{array}$ & Status \\
\hline \multirow[t]{13}{*}{1} & \multirow[t]{13}{*}{ Harga (X1) } & Pengenalan produk & 0,764 & Valid \\
\hline & & Keterjangkauan harga & 0,839 & Valid \\
\hline & & Bahan-bahan pilihan & 0,772 & Valid \\
\hline & & Kesesuaian harga dan kualitas & 0,783 & Valid \\
\hline & & Kualitas produk & 0,839 & Valid \\
\hline & & Kesesuaian dengan kemasan produk & 0,872 & Valid \\
\hline & & Kesesuaian ukuran dengan isinya & 0,782 & Valid \\
\hline & & Desain kemasan yang menunjukkan harga & 0,846 & Valid \\
\hline & & Tingkat ketebalan kemasan yang sesuai & 0,839 & Valid \\
\hline & & Merek yang terkemuka & 0,760 & Valid \\
\hline & & Tampilan menunjukkan kualitas produk & 0,860 & Valid \\
\hline & & Ragam varian produk & 0,734 & Valid \\
\hline & & Daya saing produk berdasarkan harga & 0,816 & Valid \\
\hline \multirow[t]{6}{*}{2} & \multirow{6}{*}{$\begin{array}{c}\text { Citra } \\
\text { Perusahaan } \\
\text { (X2) }\end{array}$} & Pemahaman tentang strategi bisnisnya & 0,713 & Valid \\
\hline & & Pengenalan produk-produknya & 0,716 & Valid \\
\hline & & Produk unggulan & 0,876 & Valid \\
\hline & & Posisi di pasar terhadap perusahaan lain & 0,818 & Valid \\
\hline & & Pemilik merek yang popular & 0,818 & Valid \\
\hline & & Keunggulan produk yang layak diberitakan & 0,845 & Valid \\
\hline \multirow[t]{10}{*}{3} & \multirow{10}{*}{$\begin{array}{c}\text { Keputusan } \\
\text { Pembelian (Y) }\end{array}$} & Pemenuhan kebutuhan & 0,828 & Valid \\
\hline & & Saya ingin membeli produk Wingsfood & 0,879 & Valid \\
\hline & & Manfaat produk & 0,896 & Valid \\
\hline & & Peran komposisi produk & 0,855 & Valid \\
\hline & & Pemilihan produk & 0,888 & Valid \\
\hline & & Kontrobusi terhadap mental & 0,875 & Valid \\
\hline & & Tindakan konsumsi & 0,861 & Valid \\
\hline & & Jaminan kualitas untuk membeli & 0,888 & Valid \\
\hline & & Keyakinan untuk membeli & 0,876 & Valid \\
\hline & & Kepopuleran produk yang memengaruhi perilaku pembelian & 0,777 & Valid \\
\hline
\end{tabular}

Sumber : data dioleh oleh peneliti dari output SPSS , 2020

Uji validitas berpedoman pada factor loading $>0,3$ sebagai batasan minimal, namun sangat disarankan besarnya nilai factor loading $+0,4$. Hair et al. (2010) jika factor loading suatu item pertanyaan mencapai $>0,5$ maka item sangat penting untuk menginterpretasikan konstruk yang diukurnya. Berdasarkan Tabel 2 seluruh item pertanyaan dinyatakan valid. 
Tabel 3

Uji Reliabilitas

\begin{tabular}{clcc}
\hline No & Variabel & Cronbach's alpha & Status \\
\hline 1 & Harga & 0,965 & Reliabel \\
\hline 2 & Citra Perusahaan & 0,929 & Reliabel \\
\hline 3 & Keputusan Pembelian & 0,970 & Reliabel \\
\hline
\end{tabular}

Sumber : output SPSS , 2020

Keandalan mengacu pada pengukuran yang memasok hasil yang konsisten dengan nilai yang sama. Uji reliabilitas menggunakan teknik Cronbach's Alpha dengan membandingkan nilai alpha dengan standarnya menggunakan alat bantu uji statistik SPSS 25 dengan ketentuan (1) jika Cronbach's Alpha >0,6 maka instrumen pengamatan dinyatakan reliabel; (2) jika Cronbach's Alpha <0,6 maka instrumen pengamatan dinyatakan tidak reliabel. Berdasarkan Tabel 3 hasil masing-masing variabel yaitu harga dan citra perusahaan terhadap keputusan pembelian memiliki Cronbach's alpha $>0,6$. Uji reliabilitas pada keseluruhan variabel adalah reliabel.

Menurut Gujarati (2004) uji normalitas bertujuan untuk mengetahui normalitas persamaan regresi. Normalitas dideteksi dengan melihat penyebaran titik pada sumbu diagonal dari grafik. Hasil uji normalitas data menggunakan analisis grafik yaitu grafik normal P-plot menunjukkan titik-titik menyebar di sekitar grafis diagonal serta penyebarannya mengikuti arah garis diagonal, hal ini berarti data berdistribusi normal.

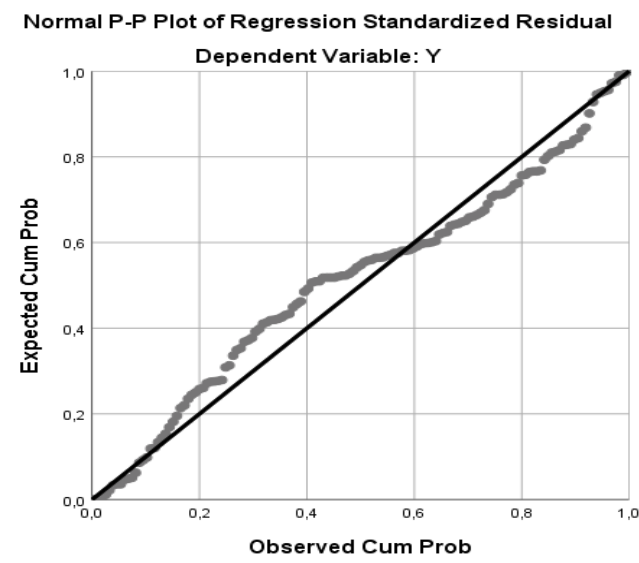

Gambar 1

Uji Normalitas

Sumber: Output SPSS, 2020

Menurut Stewart (2005) uji heteroskedastisitas dengan cara melakukan plot dan memperhatikan polanya. Plot yang terlihat seperti awan kebisingan acak tanpa pola, asumsinya kemungkinan homoskedastisitas. Bila ada jenis pengelompokan atau tren 
terdeteksi maka dianggap adalah dugaan dan perlu penilaian lebih lanjut. Hasil pengujian heteroskedisitas menunjukkan tidak terdapat pola yang jelas. Titik -titik tersebut ada yang menyebar di bawah angka empat sumbu Y. Hal ini menunjukkan bahwa model regresi yang digunakan dalam penelitian ini tidak memiliki gejala adanya heteroskedistisitas, yang berarti bahwa tidak ada gangguan dalam model regresi ini.

Uji autokorelasi menggunakan Durbin Watson (DW). Dari output SPSS diperoleh nilai Durbin - Watson sebesar 2,070. Nilai dibandingkan dengan nilai tabel menggunakan signifikansi 5\%, dengan jumlah sampel $(n=143)$ dan jumlah variabel bebas $(K=2)$ sehingga diperoleh nilai tabel $\mathrm{DL}=1,6985, \mathrm{DU}=1,7552,4-\mathrm{DU}=2,2448$, 4 -DL $=2,3015$, dengan melihat nilai Durbin - Watson yang berada diantara DU dan 4-DU dapat disimpulkan bahwa data tersebut tidak terdapat autokorelasi.

Uji multikolinieritas berpedoman pada nilai Tolerance value $>0,10$ dan VIF < 10. Dari output SPSS diperoleh nilai VIF sebesar 3,892 dan nilai tolerance sebesar 0,257. Nilai tersebut menunjukkan bahwa nilai VIF kurang 10 dan nilai tolerance lebih besar dari 0,2 sehingga semua variabel dalam tidak terkena masalah multikolinieritas atau tidak memiliki korelasi yang sangat kuat.

Tabel 4

Model Summaryb

\begin{tabular}{lcccc}
\hline Model & R & R Square & Adjusted R Square & Std. Error of the Estimate \\
\hline $\mathbf{1}$ & $0,941^{\text {a }}$ & 0,886 & 0,884 & 4,710 \\
\hline
\end{tabular}

Sumber : Output SPSS, 2020

Tabel 4 menunjukkan nilai koefesien determinasi sebesar 0,886. Hal ini berarti sekitar 88,6 \% keputusan pembelian dapat dijelaskan oleh variabel harga dan citra perusahaan sedangkan sisanya $11,4 \%$ dijelaskan oleh sebab-sebab lain di luar penelitian ini.

Uji $\mathrm{t}$ digunakan untuk mengetahui pengaruh variabel bebas $(\mathrm{X})$ yaitu harga dan citra Perusahaan secara parsial terhadap variabel terikat $(Y)$ yaitu keputusan pembelian. Pada Tabel 5 diketahui bahwa secara parsial variabel harga (X1) berpengaruh signifikan positif terhadap keputusan pembelian dengan signifikan 0,00 $<0,05$. Begitu pun citra perusahaan $(X 2)$ berpengaruh signifikan positif terhadap keputusan pembelian dengan signifikan 0,000 <0,05. 
Tabel 5

Coefficientsa

\begin{tabular}{lccccc}
\hline \multirow{2}{*}{ Model } & \multicolumn{2}{c}{$\begin{array}{c}\text { Unstandardized } \\
\text { Coefficients }\end{array}$} & \multirow{2}{*}{$\begin{array}{c}\text { Standardized } \\
\text { Coefficients }\end{array}$} & t & Sig. \\
\cline { 2 - 4 } & $\mathrm{B}$ & Std. Error & Beta & & \\
\hline (Constant) & $-2,211$ & 2,130 & & $-1,038$ & 0,301 \\
\hline Harga & 0,387 & 0,049 & 0,443 & 7,863 & 0,000 \\
\hline Citra Perusahaan & 0,869 & 0,092 & 0,532 & 9,425 & 0,000 \\
\hline
\end{tabular}

Sumber : Output SPSS, 2020

Berdasarkan Tabel 5 nilai signifikan masing-masing variabel telah memenuhi syarat dibawah 0,05 maka model regresi yang terbentuk adalah : $\mathrm{Y}=-2,211+0,387$ X1+ 0,869X2. Konstanta sebesar $-2,211$ menyatakan bahwa jika tidak ada harga dan citra perusahaan maka keputusan pembelian sebesar -2,211. Koefisien regresi X1 sebesar 0,387 menyatakan bahwa setiap penambahan satu poin harga akan meningkatkan keputusan pembelian sebesar 0,387. Koefisien regresi X2 sebesar 0,869 menyatakan bahwa setiap penambahan satu poin citra perusahaan akan meningkatkan keputusan pembelian sebesar 0,869.

Berdasarkan hasil uji F pada Tabel 6 diperoleh F hitung adalah 541,798 dengan tingkat signifikansi sebesar 0,000. Probabilitas tersebut lebih kecil dibandingkan dengan 0,05 sehingga model regresi dapat dipakai untuk memprediksi variabel keputusan pembelian. Variabel harga dan citra perusahaan secara simultan berpengaruh terhadap keputusan pembelian.

Tabel 6 ANOVA $^{\mathrm{a}}$

\begin{tabular}{llccccc}
\hline & Model & Sum of Squares & df & Mean Square & F & Sig. \\
\hline $\mathbf{1}$ & Regresion & 24036,561 & 2 & 12018,280 & 541,798 & $0,000^{\mathrm{b}}$ \\
\cline { 2 - 7 } & Residual & 3105,509 & 140 & 22,182 & & \\
\cline { 2 - 4 } & 27142,070 & 142 & & & \\
\hline
\end{tabular}

Sumber : Output SPSS, 2020

Berdasarkan hasil uji hipotesis dinyatakan semua hipotesis terbukti benar. Hipotesis pertama menyatakan bahwa harga berpengaruh signifikan terhadap keputusan pembelian produk. Temuan ini mendukung temuan Ahmetoglu et al. (2010); Al Hakim dan Arifin. (2017); Darmawan (2017); Sinambela (2017); dan Arifin et al. (2018). 
Ahmetoglu et al. (2010) pada penelitiannya menyatakan harga memberikan pengaruh signifikan terhadap niat untuk membeli. terutama harga referensi yang paling memengaruhi sementara pelanggan tidak sanggup membandingkan dengan merek lain. Oleh karena itu, masuk akal untuk mengharapkan bahwa setidaknya beberapa praktik penetapan harga akan memiliki berpengaruh pada keputusan dan perilaku konsumen ketika hal itu berfungsi sebagai isyarat yang menyederhanakan keputusan.

Hipotesis kedua terbukti benar bahwa citra perusahaan berpengaruh signifikan terhadap keputusan pembelian. Hasil penelitian ini didukung oleh penelitian yang dilakukan Cretu dan Brodie (2007). Citra perusahaan memiliki pengaruh kuat pada keputusan pembelian. Citra merek mampu memberi pengaruh yang lebih spesifik pada persepsi pelanggan terhadap kualitas produk, sementara citra perusahaan memiliki pengaruh yang luas pada persepsi nilai pelanggan dan loyalitas pelanggan. Hasil lain yang mendukung temuan ini adalah penelitian yang telah dilakukan Tat Keh dan Yi XIe (2009) yang menunjukkan bahwa citra perusahaan memiliki pengaruh positif pada kepercayaan pelanggan dan identifikasi pelanggan. Komitmen pelanggan memediasi hubungan antara dua konstruksi relasional kepercayaan pelanggan dan identifikasi pelangan) dan niat perilaku. Faktor penentu utama antara citra perusahaan dan niat pembelian pelanggan serta kemauan untuk membayar harga premium. Menurut Nguyen dan Leblanc (2001) dalam lingkungan kompetitif saat ini, reputasi perusahaan dan citra perusahaan diakui memiliki potensi untuk berdampak pada loyalitas pelanggan terhadap perusahaan. Tingkat loyalitas pelnggan memiliki kecenderungan untuk menjadi lebih tinggi ketika persepsi reputasi perusahaan dan citra perusahaan sangat menguntungkan. Selain itu, penambahan interaksi antara kedua kontruksi berkontribusi untuk lebih menjelaskan loyalitas pelanggan.

Hipotesis ketiga menyatakan bahwa secara simultan, harga dan citra perusahaan memberikan pengaruh yang signifikan terhadap keputusan pembelian. Hal ini menjadi pendukung yang kuat terhadap temuan sebelumnya yang menunjukkan pengaruh signifikan secara parsial. Sebagai sumber informasi yang terpercaya, seseorang dapat menggunakan harga dan citra perusahaan sebagai dasar pengambilan keputusan pembelian bila mereka tidak memiliki informasi selain itu. 


\section{KESIMPULAN}

Berdasarkan penelitian ini maka dapat disimpulkan : (1) harga berpengaruh signifikan terhadap keputusan pembelian produk Wingsfood di kota Mojokerto; (2) citra perusahaan berpengaruh signifikan terhadap keputusan pembelian produk Wingsfood di kota Mojokerto; (3) harga dan citra perusahaan berpengaruh simultan terhadap keputusan pembelian produk Wingsfood di kota Mojokerto.

Wingsfood telah dikenal masyarakat dengan harga produknya yang terjangkau. Selain itu citra merek masing-masing produknya telah dikenal juga dengan baik. Wingsfood dapat memperluas produk dan mereknya untuk memasuki bagian pasar yang masih potensial untuk dikuasai lebih banyak. Hal itu dapat dilakukan dengan tetap menawarkan harga yang terjangkau dan kekuatan merek yang dibangun dengan bantuan merek produk maupun reputasi perusahaan. Wingsfood juga disarankan untuk memperkuat reputasi dan citra korporasi agar mendukung citra merek produk-produknya. Upaya memperkuat reputasi dan citra korporasi dapat dilakukan dengan berbagai kegiatan bauran promosi. Untuk penelitian selanjutnya agar dapat mengembangkan hasil penelitian ini maka disarankan untuk menambahkan variabel lainnya yang berhubungan dengan keputusan pembelian karena keberagaman variabel tentu dapat menggambarkan perilaku konsumen lebih lengkap dan lebih luas.

\section{DAFTAR PUSTAKA}

Ahmetoglu G, Fried S, Dawes J, \& Furnham A. (2010). Pricing Practices: Their Effects on Consumer Behaviour and Welfare. Mountain View Learning-teaching Brain Science to Business. 3.

Al Hakim, Yusuf Rahman. \& Samsul Arifin. (2017). Pengaruh Citra Merek Dan Harga Terhadap Keputusan Pembelian Produk Rokok, Jurnal Agrimas, 1(1), 29-38

Cretu, Anca E \& Roderick J Brodie. (2007). The Influence of the Brand Image and the Reputation of the Company where Producers Market Small Companies, customer value perspective. Industrial Marketing Management, 36(2):230-240.

Arifin, Samsul., Yusuf Rahman Al Hakim, Fajar Purwanto. (2018). Pengaruh Harga dan Gaya Hidup Terhadap Minat Mahasiswa Membeli Kerupuk Samiler di Kota Mojokerto, Jurnal Agrimas, 2(1), 23-32

Barney, J.B. (1991). Firm Resources and Sustained Competitive Advantage, Journal of Management, 17(1), 99-120. 
Berman, B., \& Evans, J. R. (1995). Retail Management, 6th ed., New York: McMillan Publishing Co.

Briesch, Richard A., Lakshaman Krishnamurthi, Tridib Mazumdar, S. P. Raj. (1997). A Comparative Analysis of Reference Price Models, Journal of Consumer, 24, 202-214.

Brown, Tom J dan Peter A.Dacin .(1997). The Company and the Product corporate associations and Consumer Product Responses, Journal of Marketing, 61 (1), 68-84

Carter, S. \& Deephouse, D. (1999). "“Tough talk" and "soothing speech": Managing Reputations for being Tough and for being Good, Corporate Reputation Review, 2, 308-332.

Cannon, H. M., \& Schwaiger, M. (2005). The Role of Company Reputation in Business Simulations. Simulation E Gaming, 36, 188-202.

Chakrabartty, S.N. (2013). Best Split-Half and Maximum Reliability, Journal or Research \& Method in Education. 3 (1),1-8.

Darmawan, Didit. (2011). Pengantar Manajemen Merek. Surabaya : Metromedia

Darmawan, Didit. (2014). Perilaku Konsumen. Surabaya : Metromedia

Darmawan, Didit. (2015). Metodologi Penelitian. Surabaya: Metromedia.

Darmawan, Didit. (2017). Pengaruh Kemasan dan Harga Terhadap Keputusan Pembelian Produk Sayuran Hidroponik, Jurnal Agrimas, 1 (1), 1-10

Darmawan, Didit. (2019). Kualitas Produk, Kesadaran Merek dan Harga serta Pengaruhnya Terhadap Kepuasan Pelanggan, Jurnal Administrasi Bisnis, 8 (2), 75-88

Darmawan, D., Mardikaningsih, R., Arifin, S., \& Hariani, M. (2019). Upaya Memperkuat Citra Ramayana Departemen Toko Melalui Promosi Penjualan Dan Periklanan. Akuntabilitas: Jurnal Ilmiah Ilmu-Ilmu Ekonomi, 12 (1), 59-71.

Dickson, P. R., A. G. Sawyer. (1990). The Price Knowledge of Supermarket Shoppers. Journal of Marketing 54 (July) 42-53.

Dollinger, M., Golden, P. \& Saxton, T. (1997). The Effect of Reputation on the Decision to Joint Venture, Strategic Management Journal, 18, 127-140.

Durmaz. Y \& Jablonski. S. (2012). Integrated Approach to Factors Affecting Consumers Purchase Behavior in Poland and an Empirical Study. (JMBR), Volume 12 Issue 15. [4]

Fombrun, C. \& Shanley, M. (1990). What's in a name? Reputational building and corporate strategy, Acad-emy of Management Journal, 33, 233-258.

Gatewood, R.D., Gowan, M.A. and Lautenschlager, G.J. (1993). Corporate Image, Recruitment Image and Initial Job Choice Decisions', Academy of Management Journal, 36(2), 414-427.

Gujarati Damodar N. (2004)." Basic Economics". Fourth Edition. Singapore: Mc.Grawhill Inc.

Hair, J. F. Jr., William, C. B, Banin, B. J \& Anderson, R. E. (2010). Multivariate Data Analysis $7^{\text {th }}$ edition. New Jersey: Upper Saddle River-Prentice Hall.

Hall, R. (1993). A Framework Linking Intangible Resources and Capabilities to Sustainable Advantage', Strategic Management Journal, 14(8), 607-618.

Hean Tat Keh, Yi Xie. (2009). Corporate Reputation and Customer Behavioral Intentions : The Roles of Trust, Indentification and Commitment, Industrial marketing management,.38 (7),732-742.

Pengaruh Harga dan Citra Perusahaan terhadap Keputusan Pembelian Produk Wingsfood 
Herbig, P., Milewicz, J. and Golden, J. (1994) 'A Model of Reputation Building and Destruction', Journal of Business Research, 31, 23-31.

Ishaq, Ishtiaq. (2012). Perceived Value, Servise Quality,Corporate Image and Customer Loyalty, Serbian Journal of Management, 7, 25-36.

Kotler, P. dan Kevin Lane Keller. (2012). Marketing Management $14^{\text {th }}$ edition. Jakarta : PT Indeks Kelompok Gramedia.

Kotler, P., \& Armstrong, G.M., (2006). Principles of Marketing 11th Edition. Upper Saddle River, NJ: Pearson Education, Inc.

Krishna, A., Currim, I. C. \& Shoemaker, R. (1991). Consumer Perceptions of Promotional Activity. Journal of Marketing, 55(2), 4-16.

Naehyun et al. (2016). The effect of image price fairness, International Journal of Contemporary Hospitality Management, Vol.28 Issue:9,pp 1895-1914.

Nguyen, N. \& G. Leblanc. (2001). Corporate Image and Corporate Reputation in Customers' Retention Decisions in Services, Journal of Retailing and Consumer Services, 8 (4), 227-236

Thomson (2013).Analisis Pengaruh Kualitas Pelayaanan Konsumen pada warung ucok Durian Iskandar Muda Medan terhadap Keputusan Pembelian.FE USU

Blackwell, R., P. W. Miniard \& J. F. Engel, (2006). Consumer Behavior, 10th ed. Thomson, Ed. South-Western: Cengage Learning

Satit Rezky Purna., Tat HH, Rasli A, Chin TA, \& Sukati I. (2012). The Relationship Between Marketing Mix And Customer Decision-Making Over Travel Agents: An Empirical Study. International Journal of Academic Research in Business and Social Scienes, 2 (6), 522-530 .

Schiffman,L \& Kanuk L.L (2008). Perilaku Konsumen Edisi7, Jakarta : Indeks

Shapiro, C. (1983). Premiums for High Quality Products as Returns to Reputations, Quarterly Journal of Economics, 98(4), 659-679.

Sinambela, Ella Anastasya. (2017). Pengaruh Ekuitas Merek dan Harga terhadap Keputusan Pembelian Produk Kopi Bubuk Kemasan, Management E Accounting Research Journal, 1(2), 44-49

Sinclair, C. (2007). Packing a Punch:Using Pacakging as Effective Advertising and Communication to Build Your Bottom Line, Market Research Society, Annual Conference.

Senecal, S. \& Nantel, J. (2004). The Influence of Online Product Recommendations on Consumers' Online Choices, Journal of Retailing, 80(2), 159-169

Stewart, K.G. (2005). Introduction to applied econometrics. Cole Belmont, CA: Thomson Brooks. Weigelt, K. \& Camerer, C. (1988). Reputation and Corporate Strategy: A Review of Recent Theory and Applications, Strategic Management Journal, 9(5), 443-454.

Weiwei, Tang. (2007). Impact of Corporate Image and Corporate Reputation on Costomer Loyalty: A Review. Journal Management Science and Engineering, 1(2), 57-62

Vanhuele, M. \& Drèze, X. (2002). Measuring the Price Knowledge Shoppers Bring to the Store, Journal of Marketing, 66(4), 72-85.

Zeithaml,Valerie. A. (1988). Consumer Perceptions of Price, Quality, and Value : A Mens-End Model and Synthesis of Evidence, Journal of Marketing, 52(3), 2-22 